\title{
The effects of using virtual reality in the rehabilitation of stroke patients: Systematic review
}

\author{
Letícia de S. Vidal, ${ }^{1 *}$ Lilian Maria M. C. de Oliveira, ${ }^{1}$ Tassiane Maria A. Pereira, ${ }^{2-4}$ Janaína de M. Silva ${ }^{5-7}$
}

\begin{abstract}
Introdution: Stroke causes several alterations, the more frequent are motor, physical and psychological. Since rehabilitation takes time and can become monotonous, the use of virtual reality can act as a stimulating way to involve the patient in the treatment, seeking to develop its functionality. Objective: The objective of this study was to verify in the available literature the effects of using virtual reality in the treatment of the sequelae of the Stroke, to gain functionality in the upper limbs. Methods: This literature review was based on the PICO strategy, carried out in the databases Lílacs, Pubmed, Scielo and PEDro, using the keywords "physiotherapy AND virtual reality OR exergame OR exergaming AND stroke AND upper limbs". Complete articles were published in English, Portuguese and Spanish, available and dated between 2015 and 2020, excluding those that were review articles, incomplete and that did not address the topic. Results: As a result, the search found 1,035 articles, of which only 14 met the imposed criteria. Most studies have shown that the use of virtual reality through games has proved to be an efficient resource in the functional rehabilitation of patients with stroke. Presenting itself as a competent complementary to physiotherapeutic treatment in improving fine motor skills, motor behavior of the limbs and cognitive performance, these gains directly influenced the gain in functionality of the samples. Conclusion: The use of virtual reality is useful to assist in the treatment and reduction of sequelae in the upper limbs of patients with stroke, as it promotes greater functional gain, range of motion and improves the dexterity of both the most and the least compromised hand.
\end{abstract}

Keywords: Physiotherapy; Virtual reality; Stroke; Upper limbs.

\section{Introduction}

In general, the stroke occurs due to blood irrigation problems, either in an ischemic form when it is caused by a localized vascular occlusion, or in a hemorrhagic form that occurs when a brain blood vessel ruptures with blood leakage, either way, both will culminate in the reduction of oxygen and glucose in brain regions. Some factors such as sedentary lifestyle, obesity, hypertension, atherosclerosis and other heart diseases can increase the likability of a person to develop the stroke, as it occurs due to blood irrigation problems, either in an ischemic forcing one of the types of stroke. ${ }^{1-3}$

In addition, stroke can cause muscle, somatosensory, psychological, cognitive and social damage. One of the most common sequelae, however, is hemiplegia,
1. Curso de Graduação em Fisioterapia, Universidade Estadual do Piauí (UESPI). Teresina, PI, Brazil.

2. Curso de Graduação em Fisioterapia, Centro Universitário Maurício de Nassau (UNINASSAU). Teresina, PI, Brazil.

3. Curso de Especialização em Fisioterapia Hospitalar, Faculdade Inspirar. Teresina, PI, Brazil.

4. Programa de Mestrado em Biotecnologia, Universidade Federal do Delta do Parnaíba (UFDPAR). Parnaíba, PI, Brazil.

5. Curso de Especialização em Fisioterapia, Universidade Estadual do Piauí (UESPI). Teresina, PI, Brazil.

6. Curso de Especialização em Engenharia Biomédica, Universidade do Vale do Paraíba (UNIVAP). São José dos Campos, SP, Brazil.

7. Curso de Especialização em Ciências Biomédicas, Universidade Federal do Piauí. Parnaíba, PI, Brazil.

*Correspondence address:

Residencial Manoel Evangelista I, Bairro Novo Horizonte,

Rua 21, casa 13

Teresina, Piauí, Brazil. CEP 64079-112.

E-mail: leticicias2vidal@gmail.com

ORCID: https://orcid.org/0000-0001-6988-8798

BJHBS, Rio de Janeiro, 2021;20(1):73-83

DOI: 10.12957/bjhbs.2021.59749

Received on 09/29/2020. Approved on 02/10/2021.

which causes difficulties in performing simple daily activities, as well as care, treatments and functional independence of that individual. Although the treatment of post-stroke patients is multidisciplinary, physiotherapy acts directly and, in general, both in reducing motor and/or sensory impairments, through the gain of ROM and muscle tone, as well as in cognitive, through the increase of balance and proprioception. When specifically related to the upper limbs, it is possible to obtain greater coordination, manual dexterity, develop motor learning, as well as improve the execution of arm movements as a whole. All exercises aiming at gaining functionality. The patient's lack of adherence to conventional therapeutic approaches, however, negatively influence the recovery of this individual. ${ }^{48}$

Furthermore, in order to make physiotherapy services more attractive, making them less repetitive or monotonous, the virtual world can promote greater patient interaction in therapy by inserting him in an environment that arouses his motivation and pleasure 


\section{Review article}

when exercising. Virtual Reality (VR) works as a computer system that allows the creation of an artificial environment, through which, the user can not only feel inside this environment, but also interact with it in real time, promoting a comprehensive experience by stimulating various senses such as sight, touch and hearing, mostly at the same time..$^{9-11}$

In view of the various applicability of VR, it can be differentiated according to the way that the user interacts with the virtual environment and with the equipment used, being classified into immersive VR and non-immersive VR, or just Augmented Reality (AR). Immersive VR aims to isolate the individual from the real world, so that a special equipment is needed to block the individual to the real environment, causing their senses to be stimulated only by the computer system, through glasses, helmets, special gloves. On the other hand, in Augmented Reality the user is not isolated from the real environment, it is just an enrichment of the real world with virtual objects, in real time allowing the use of more accessible equipment, such as a computer, mouse, smartphone. There is still Mixed or Mixed Reality, which is the combination of the two types. However, the most used ones associated with therapies with different objectives are the Nintendo-Wii ${ }^{\circledR}$, PlayStation ${ }^{\circledR}$ and Xbox 360 kinect, both of AR, in which the games were not designed for patients with motor problems. However, they provide a great improvement in motor function as they require the practice of specific activities that involves a greater number of repetitions. Hence, conventional Physiotherapy science added to the dynamism and playfulness of VR can generate better results. ${ }^{12-16}$

Bearing in mind that in addition to being an alarming public health problem, stroke can cause several sequelae, physiotherapy seeks to reduce general impairments through the use of VR that can increase patient compliance. It may also help he/she to gain functionality in a more playful way. The objective of this work is to search the available literature and critically analyze the effects of using VR on the gain of motor functionality in the upper limbs of stroke patients.

\section{Materials and methods}

It is an integrative review whose bibliographic survey was carried out on the bases: Lilacs, Scielo, PUBMED and PEDro. The PICO strategy was used, the acronym PICO stands for P (Problem), I (Intervention), C (Control) and $\mathrm{O}$ (Results). In this work, C (Control) does not apply, because there was no comparison of two interventions.
Thus, the guiding question was: Is there any evidence that the use of VR can help improve the functionality of the upper limbs of patients with stroke? In addition, the keywords were: virtual reality, physiotherapy, stroke, cerebrovascular accident, stroke, virtual reality, physiotherapy, whose combinations used were "virtual reality AND stroke", "use of virtual reality in stroke", "physiotherapy and the use of virtual reality AND stroke "," physiotherapy and virtual reality and stroke ", exergame OR exergaming OR virtual reality AND upper limbs. To be included in this review, the studies identified by the search strategy should consist of research that used virtual reality in patients with stroke sequelae aiming at gaining functionality in upper limbs published in the last 5 years (2015-2020), as well as articles in Portuguese, English and Spanish and available in full. PEDro Scale was also applied to verify and show the quality of the selected studies in order to improve the conclusions about the study, in addition to excluding review articles, reports or case series, as well as studies whose sample was not an adult population.

\section{Results}

A total of 1,035 articles were found, 93 of which were selected for a careful evaluation and of these, 79 did not fit the eligibility criteria, thus, only 14 were included in the research, and of these $92.85 \%$ of them used not immersive VR, while only $7.15 \%$ of them used immersive VR. As for the types of study: $14.29 \%$ were of the controlled and randomized type; $14.29 \%$ of the blind, controlled, randomized and multicentric type; $14.29 \%$ described only as experimental; $21.43 \%$ of the blind, controlled and randomized type, and among the $35.70 \%$ of them, there are studies of varied types, such as double blind clinical trials, double blind pilot studies; blind, simple and randomized and randomized, parallel and multicentric group. As for the objectives of the studies, $57.15 \%$ of them sought to gain functionality in the secondary outcome, with $42.85 \%$ seeking it in the primary outcome. Thus, the articles used aimed at gains: cognitive (14.29\%); independence (14.29\%); motor function (57.15\%); sensory function (7.15\%); manual dexterity, gross (14.29\%); range of movement (21.43\%); motor learning (14.29\%); adherence and motivation (50\%) and feasibility and security (21.43\%). (Figure 1)

The information presented in the included articles was summarized in the following topics: author/year, type of study and sample, intervention, analyzed variables, outcomes, results and PEDro Scale (see Tables 1 to 6). 


\section{Discussion}

According to the studies found, the use of VR games provided the improvement of motor physical function $^{17-20}$ and sensory function of the most compromised hand, ${ }^{17}$ as well as of gross manual dexterity, ${ }^{21}$ active range of motion ${ }^{18}$ for shoulder flexion, ${ }^{22,23}$ also developing motor learning,,$^{19,21}$ and in addition to the functional improvements, improvement in treatment adherence and motivation during conventional therapy can be demonstrated. ${ }^{24-27}$ However, some studies emphasize that the achievement of these improvements may not have happened due to the exercises performed in VR therapy, but because of the greater adherence promoted by virtual games, compared to conventional therapy, because it makes it more inviting and diversified. ${ }^{22,26,27}$
The smallest sample of selected articles was 10 participants and the largest was 65 , with the remaining studies ranging from 20 to 30 individuals, with few dropout rates among them, however, the results were similar and VR therapy was, generally applied in association with conventional therapy, known as "mixed therapy". ${ }^{17,21,19}$ In addition, some studies have added, in addition to conventional physiotherapy, occupational therapy as well. And in these, the VR influence scores on cognitive development and motor learning were higher, highlighting the importance of treating patients with stroke in a multidisciplinary way. $18,23,25,29,28$

As for the duration of the sessions, they ranged from 30 to 45 minutes. One of the studies left the session time open, as the VR device would be installed in the patient's

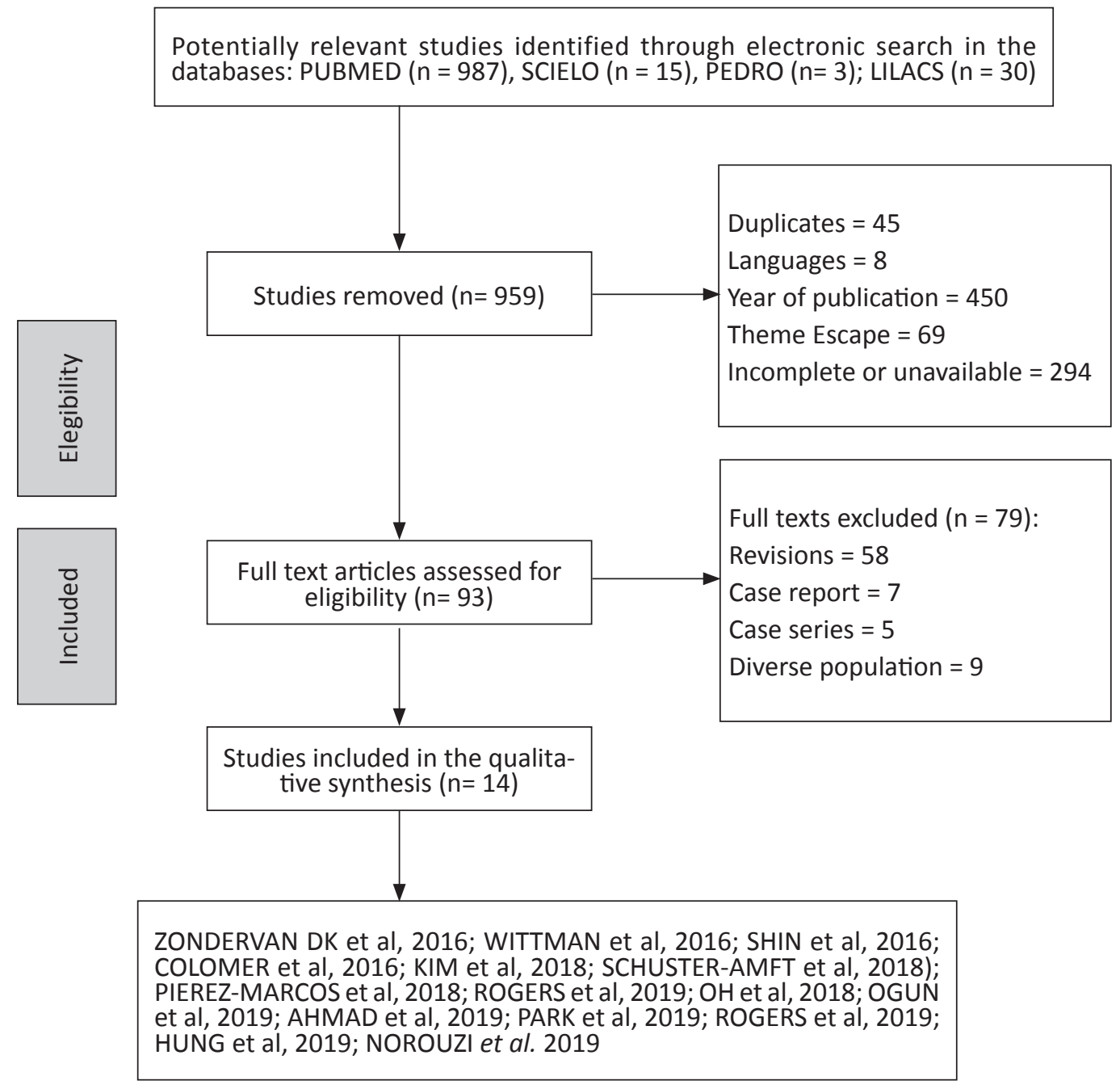

Figure 1. Flowchart of article selection

Authorship: The authors (2020) 


\section{Review article}

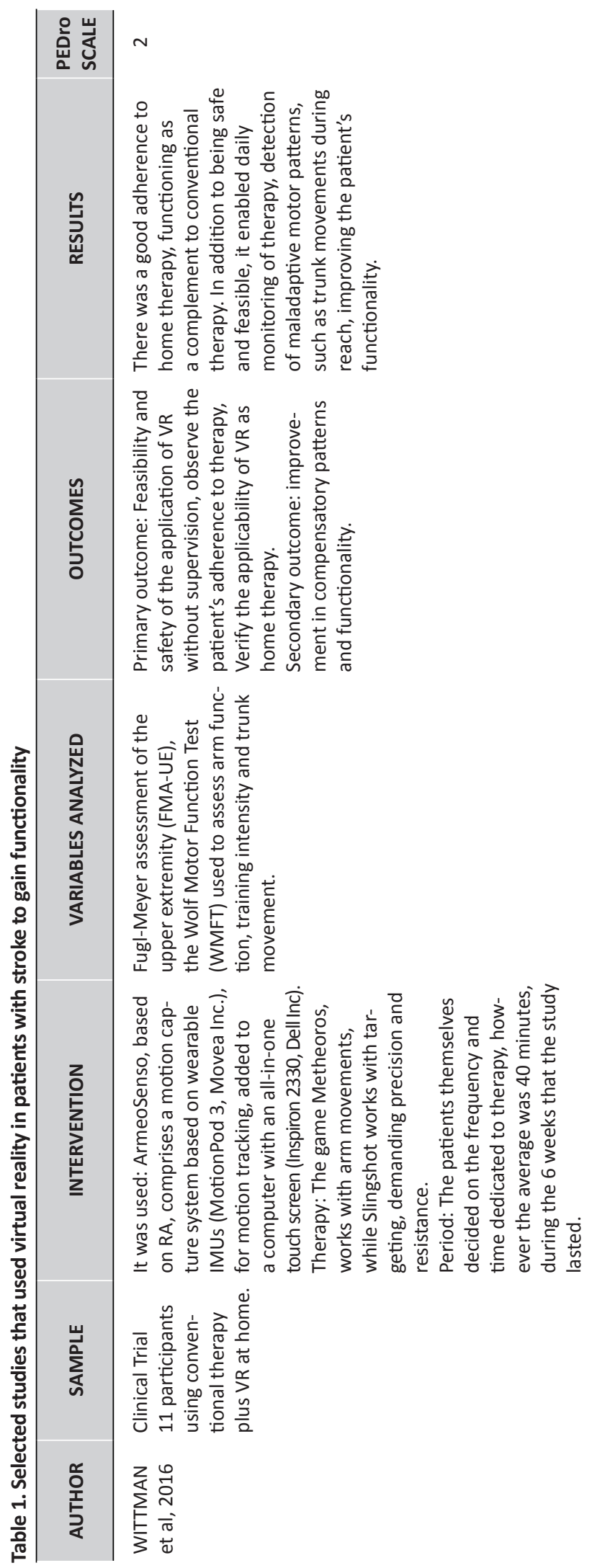

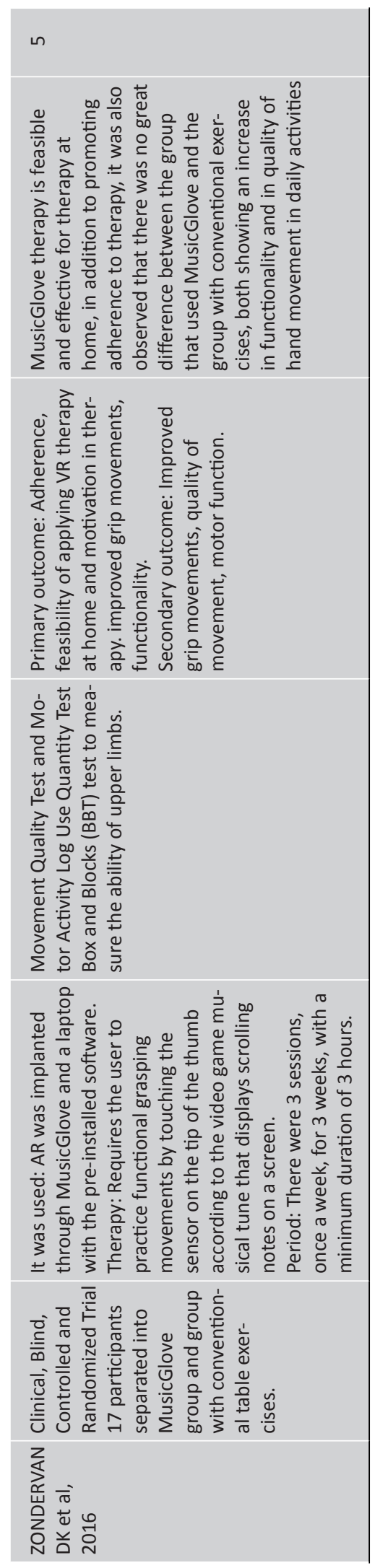



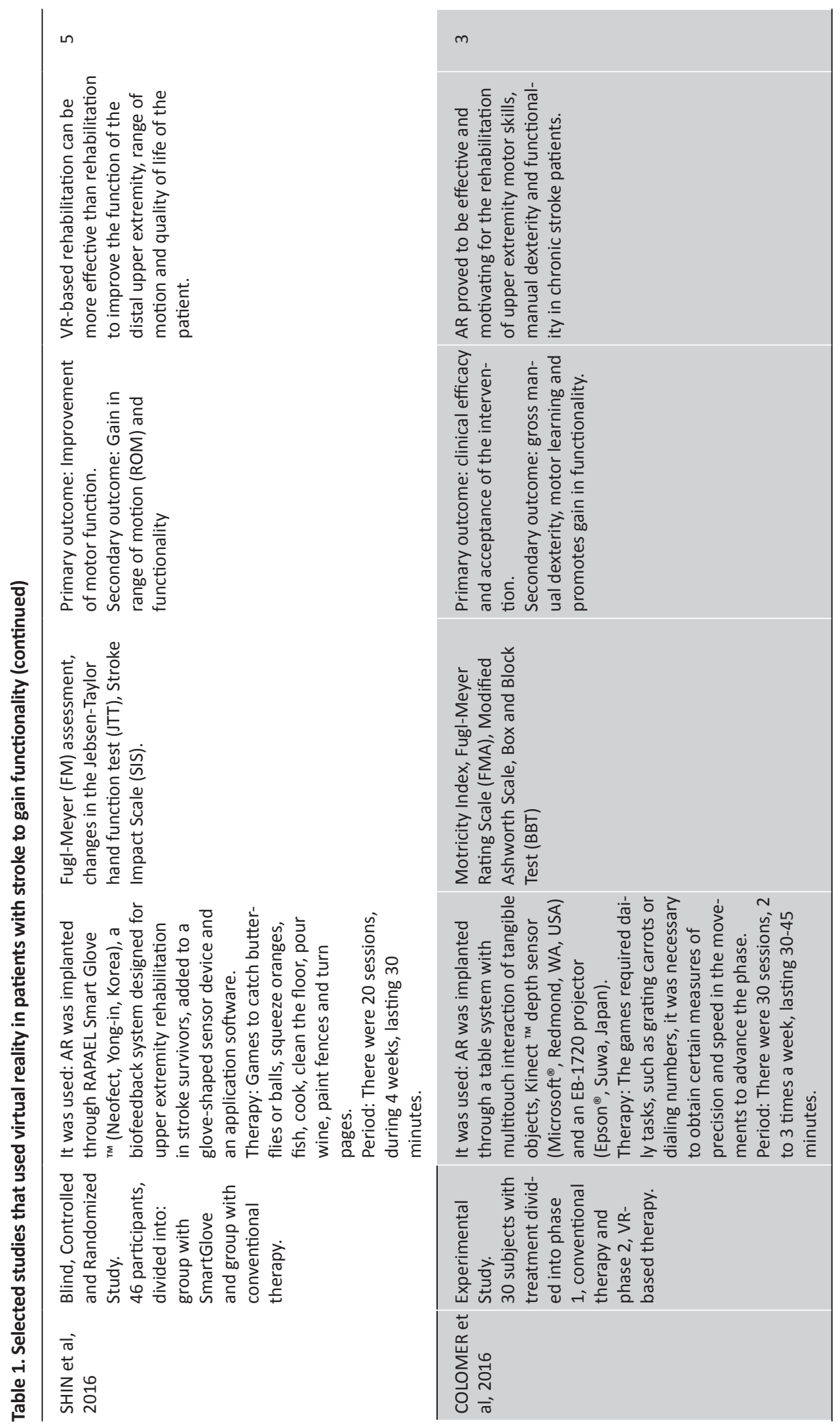


\section{Review article}

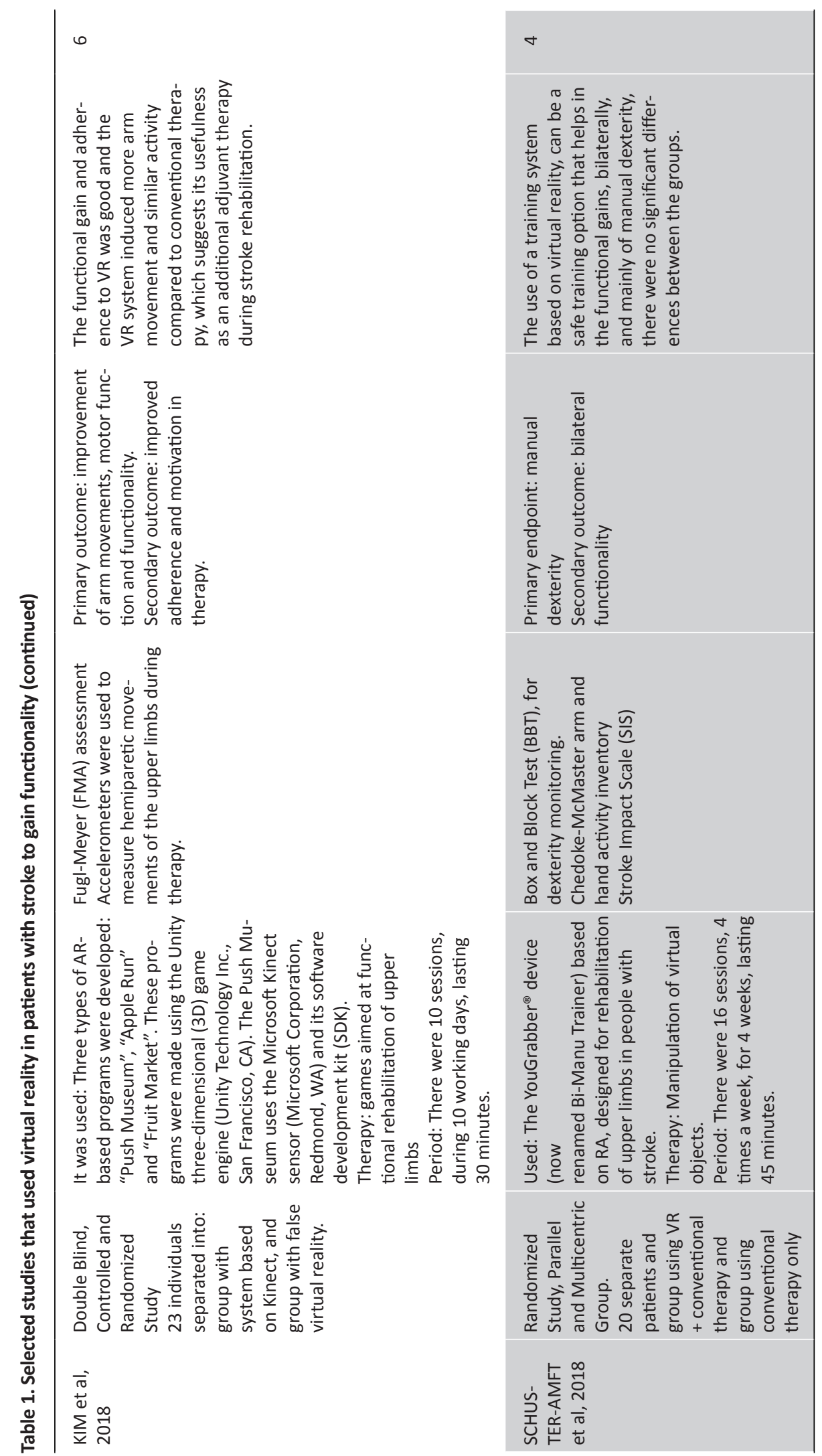




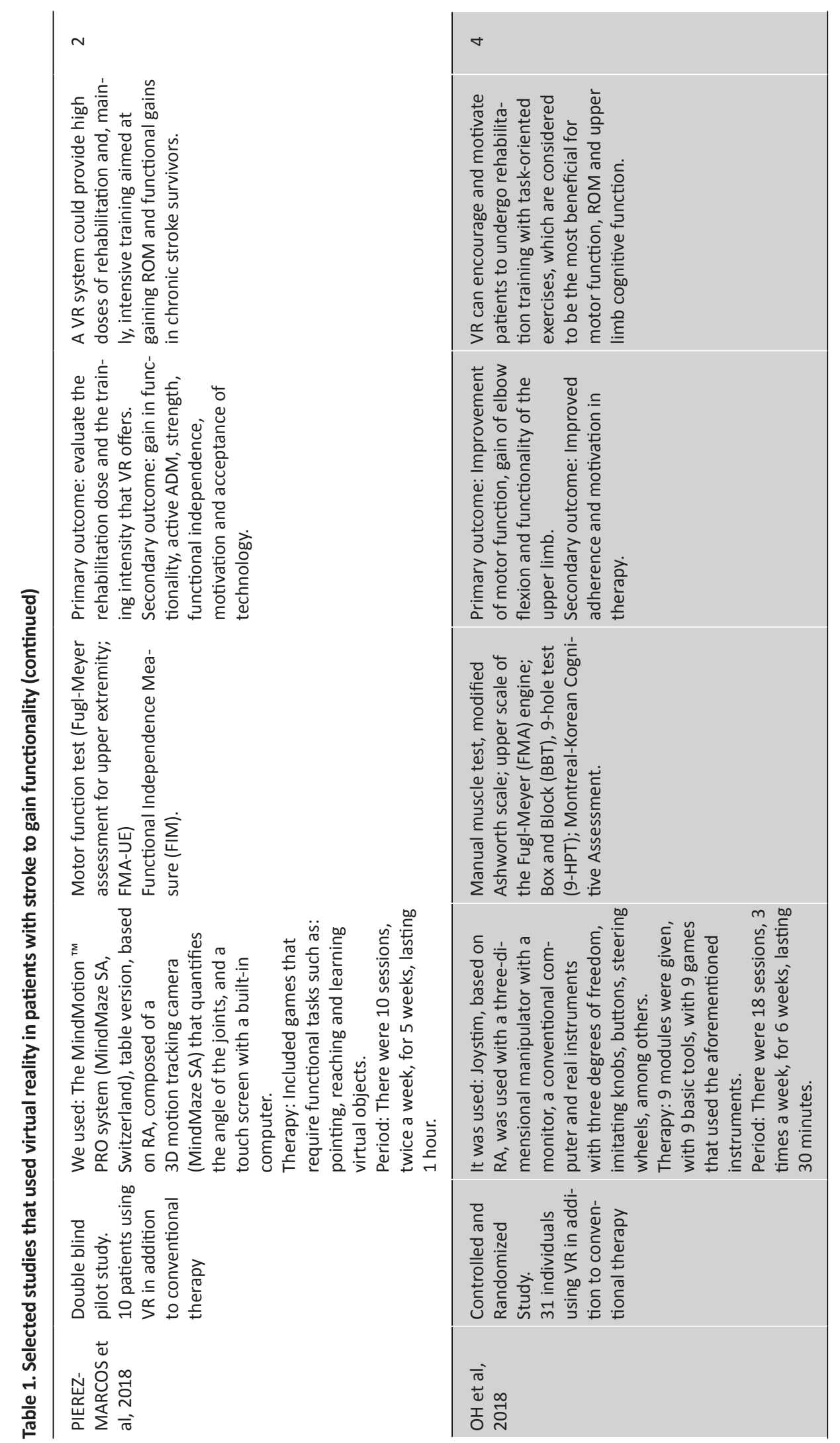




\section{Review article}

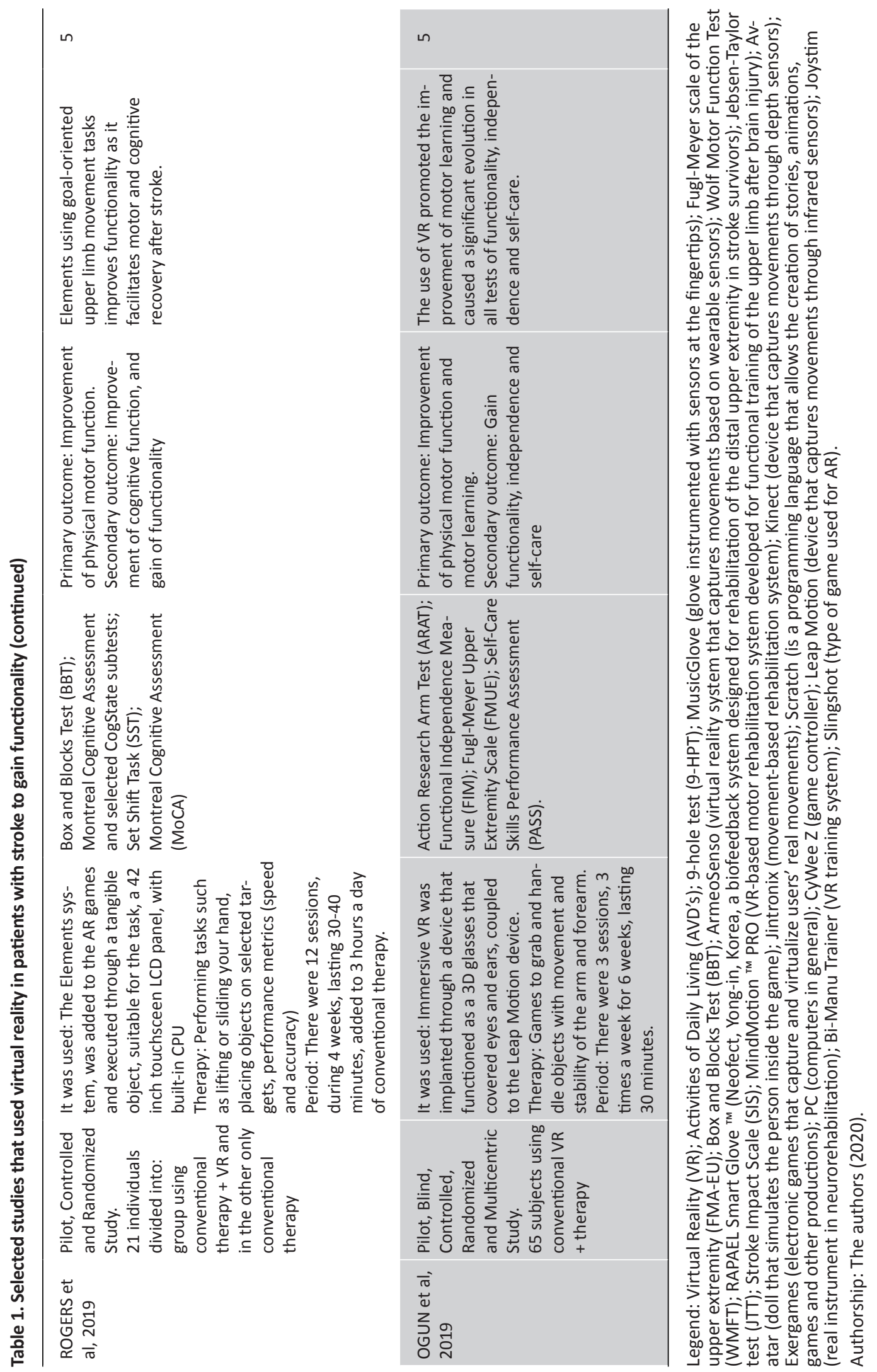


home, and aimed not only to verify the effect of VR, but also the patient's adherence to therapy and, as a result, the study showed that the games were used for a minimum of 8 minutes and a maximum of 41 minutes, and patients who used VR therapy for less time were in the chronic phase of the stroke. This information highlights that the adherence to therapy is greater in patients with more acute sequelae, ${ }^{30}$ which is related to another study in which they applied VR therapy for 60 minutes and found that after the initial 10 minutes, patients with chronic stroke show fatigue, as well as have reduced the quality of movement. ${ }^{19}$ Such observation suggests that therapy with the use of VR in patients with chronic sequelae, showing less adherence, should still be administered for less time to avoid fatigue in patients.

To really verify the gains obtained with VR, studies used several scales and tests scientifically validated, among them the Fugl-Meyer Assessment (FMA), which stands out as the best known, 17,18,19,23,22,25,28,30 Stroke Impact Scale (SIS), 17,18,23,28,29 Functional Independence Measure (FIM), 19,22 Box and Block Test (BBT), 20,21,24-26,28,29, Wolf motor function test (WMFT), 17,23,27,30 Self-Care Skills Performance Assessment (PASS) ${ }^{19}$ and the Pittsburgh Participation Scale (PPS). ${ }^{27}$ However, the scales in which the intervention generated the best results were PASS, FMA and BBT, while in the others, the results obtained were not very significant. Yet, one of the studies did a one-month follow-up and the functional and cognitive benefits were being maintained only with conventional therapy. ${ }^{20}$

Most articles used VR games as a means to obtain motor and cognitive functionality, however some of the articles emphasized that in addition to functionality gains, VR systems can work as a means of avoiding compensatory movements in or near the segment being worked on, as well as more distal segments where the therapy is being applied, such as the trunk. ${ }^{21,30}$ This is in line with studies that have worked with VR, both immersive and non-immersive, in which they reported that these systems, by providing visual feedback in real time, can favor self-correction aiming at reducing excessive movements or deviating from normal. ${ }^{19,28}$

Only one study used immersive VR using 3D glasses and obtained several functional gains and mainly motor learning. ${ }^{19}$ However, the vast majority of studies used non-immersive VR using equipment such as ArmeoSenso, ${ }^{30}$ Jintronix ${ }^{\circledR},{ }^{28}$ Kinect2Scratch ${ }^{\circledR 27}$ and also acquired significant gains, not only in terms of functionality but also in terms of adherence to treatment, this is probably due to ease of application, as well as, because it does not require very specific equipment, and some authors stated its safety and applicability at home, ${ }^{26,30}$ aiming mainly to continue the treatment already acquired in the hospital or clinic, because, in addition to demonstrate to be a low-cost therapy, ${ }^{24}$ it can still be applied without the therapist, only with initial instructions, this would be useful for patients who live in areas very distant from the Rehabilitation Centers, however frequent follow-ups are necessary to ascertain the evolution of the treatment. ${ }^{21,24}$

However, in all the articles presented, VR was used associated with conventional treatments, thus, the gains obtained are related both to the efficiency of application and adherence to VR therapy, as well as to the methods used in conventional therapy, which were not strictly applied. detailed in most of the articles. Despite the diversity of methodologies and duration of interventions, the biggest and most common gains obtained were from motor functionality of the most compromised hand, ROM, coordination and manual dexterity. Therefore, further research is needed, with a better description of the forms and applications of conventional therapies, as well as studies that standardize only one type of technology or game, describing and characterizing, even in the methodology, the type of VR used, whether immersive, non-immersive or mixed, to achieve clearer results on the effects of VR in the treatment of sequelae of the upper limbs of a patient with stroke.

\section{Final considerations}

The results of this review showed that VR is efficient in terms of gaining motor functionality of the upper limbs as it provides, as main effects, gain in range of motion, improved dexterity, motor function and function, both in the hand and in the less compromised patients. In addition, VR proved to be a differential in therapy, because in addition to allowing the patient to continue rehabilitation at home, it can also encourage not only adherence to conventional therapy, but induce several functional, sensory, cognitive and psychological gains. Furthermore, through VR games, regardless of their type, the patient is encouraged to seek self-correction due to the feedback, mainly visual, provided by them. It is also possible to use VR more comprehensively, aiming to perceive some compensatory movements of other segments of the body in which the therapy is not being applied, such as the trunk, and to seek to correct or reduce them. However, VR effects proved to be more relevant and noticeable in less compromised patients. 


\section{Review article}

\section{Referências}

1. Rodrigues M, Santana L, Galvão I. Fatores de risco modificáveis e não modificáveis do AVC isquêmico: uma abordagem descritiva. Revista de Medicina. 2017;96(3):187192.

2. Piassarolli C, Almeida G, Luvizoto J, et al. Modelos de Reabilitação Fisioterápica em Pacientes Adultos com Sequelas de AVC Isquêmico. Revista Neurociências. 2012;20(1):128-137.

3. Araújo J, Brandão A, Dias D. Immersive Brain Puzzle: aplicação de realidade virtual voltada à reabilitação de pacientes pósAVC. Anais Estendidos do XXI Simpósio de Realidade Virtual e Aumentada (SBC). 2019;(10):25-26.

4. Cikajlo I, Rudolf M, Mainetti R, et al. Multi-Exergames to Set Targets and Supplement the Intensified Conventional Balance Training in Patients With Stroke: A Randomized Pilot Trial. Front Psychol. 2020;(11):572.

5. Carvalho M, Bruna C, Ramalho T. Uso da realidade virtual no tratamento fisioterapêutico de indivíduos com Síndrome de Down. Revista Neurociências. 2015;23(1):143-149.

6. Rosa G. Efeito da realidade virtual na recuperação da função motora do membro superior em paciente com AVC crônico. Fisioterapia Brasil. 2016;13(5):380-383.

7. Schuster R. Efeitos da realidade virtual no equilíbrio de indivíduos hemiparéticos. Fisioterapia Brasil. 2016;15(1):49-55.

8. Ferla F, Grav M, Perico E. Fisioterapia no tratamento do controle de tronco e equilíbrio de pacientes pós AVC. Revista Neurociências. 2015;23(2):211-217.

9. Ribeiro M, Zorzal E. Realidade virtual e aumentada: Aplicações e tendências. XIII Simpósio de Realidade Virtual e Aumentada. 2011;15.

10. Kirner $\mathrm{C}$, Tori $\mathrm{R}$. Introdução à realidade virtual, realidade misturada e hiper-realidade. Realidade Virtual: Conceitos, Tecnologia e Tendências. 1ed. São Paulo. 2004;(1):3-20.

11. Cardoso A, Kirner C, Júnior E, et al. Tecnologias e ferramentas para o desenvolvimento de sistemas de realidade virtual e aumentada. Editora Universitária UFPE. 2007;1-19.

12. Silva W, Lopes G, Yano K, et al. Efeito de um programa de reabilitação usando realidade virtual para equilíbrio e funcionalidade de pacientes com AVC crônico. Motriz: rev. educ. fis., Rio Claro. 2015;3(21):237-243.

13. Santana C, Lins O, Sanguinetti D, et al. Efeitos do tratamento com realidade virtual não imersiva na qualidade de vida de indivíduos com Parkinson. Rev. Bras. Geriatr. Gerontol. 2015;1(18):49-58.

14. Deutsch J. Using virtual reality to improve walking post-stroke: translation to individuals with diabetes. J Diabetes Sci Technol. 2011;5(2):309-314.

15. Pompeu J, Alonso T, Masson I, et al. Os efeitos da realidade virtual na reabilitação do acidente vascular encefálico: Uma revisão sistemática. Motricidade. 2014;10(4):111-122.

16. Galvão M, Gouvêa P, Ocamoto G, et al. Efeito da Realidade Virtual na Função Motora do Membro Superior Parético Pós-Acidente Vascular Cerebral. Revista Neurociências. 2015;23(4):493-498.

17. Ahamad M, Singh D, Mohd N, et al. Virtual Reality Games as an Adjunct in Improving Upper Limb Function and General Health among Stroke Survivors. Int J Environ Res Public Health. 2019;16(24):5144.
18. Shin J, Kim M, Lee J, et al. Efeitos da reabilitação baseada na realidade virtual na função da extremidade superior distal e na qualidade de vida relacionada à saúde: um estudo controlado, cego e randomizado. J NeuroEngineering Rehabil. 2016;(10):13-17.

19. Ögün M, Kurul R, Yasar M, et al. Efeito do uso imersivo da realidade virtual $3 \mathrm{D}$ baseada em movimento de salto na função de extremidade superior em pacientes com AVC isquêmico. Arquivos de Neuro-Psiquiatria. 2019;77(10):681-688.

20. Rogers J, Duckworth J, Middleton S, et al. Elements virtual rehabilitation improves motor, cognitive, and functional outcomes in adult stroke: evidence from a randomized controlled pilot study. J NeuroEngineering Rehabil. 2019;(10):16-56.

21. Colomer C, Llorens R, Noé E, et al. Efeito de uma intervenção mista baseada na realidade na função do braço, mão e dedo no acidente vascular cerebral crônico. J NeuroEngineering Rehabil. 2016;(10):13-45.

22. Pierez-Marcos D, Chevalley O, Schmidlin T, et al. Aumentando a intensidade do treinamento dos membros superiores no AVC crônico usando realidade virtual incorporada: um estudo piloto. J NeuroEngineering Rehabil. 2017;(10):14-119.

23. Park M, Ko M, Oh S, et al. Efeitos de exercícios de movimento planar baseados em realidade virtual na função da extremidade superior, amplitude de movimento e qualidade de vida relacionada à saúde: um estudo piloto multicêntrico, cego, randomizado e controlado. J NeuroEngineering Rehabil. 2019;(10):16-122.

24. Kim M, Cho L, Kwon S, et al. Sistema de reabilitação virtual com base em baixo custo para reabilitação hospitalar de membros superiores em pacientes com acidente vascular cerebral subagudo. Medicina. 2018;97(25):11173.

25. Oh Y, Kim G, Han K, et al. Eficácia da realidade virtual combinada com treinamento com instrumentos reais para pacientes com AVC: um estudo controlado randomizado. Arch Phys Med Reabilitação. 2019;100(8):1400-1408.

26. Zondervan D, Freedman N, Chang E, et al. Home-based hand rehabilitation after chronic stroke: Randomized, controlled single-blind trial comparing the MusicGlove with a conventional exercise program. J Rehabil Res Dev. 2016;53(4):457-472.

27. Hung J, Chou C, Chang Y, et al. Comparison of Kinect2Scratch game-based training and therapist-based training for the improvement of upper extremity functions of patients with chronic stroke: a randomized controlled singleblinded trial. Eur J Phys Rehabil Med. 2019;55(5):542-550.

28. Norouzi N, Hernandes A, Archambault P, et al. Feasibility, Safety and Efficacy of a Virtual Reality Exergame System to Supplement Upper Extremity Rehabilitation Post-Stroke: A Pilot Randomized Clinical Trial and Proof of Principle. Int J Environ Res Public Health. 2019 Dec 23;17(1):113.

29. Schuster-Amft E, Eng K, Suica Z, et al. Effect of a four-week virtual reality-based training versus conventional therapy on upper limb motor function after stroke: A multicenter parallel group randomized trial. PLoS One. 2018;13(10):020-4455.

30. Wittmann F, Held J, Lambercy $\mathrm{O}$, et al. Terapia autodirigida do braço em casa após acidente vascular cerebral com um sistema de treinamento de realidade virtual baseado em sensor. J NeuroEngineering Rehabil. 2016;(10):13-75 